\title{
Kamu Diplomasisi ve Çin
}

\section{Elif Sak ${ }^{1}$}

\section{Özet}

Zaman içerisinde meydana gelen değişimler her alana olduğu gibi diplomasi alanına da yansımıştır. Özellikle teknoloji alanında yaşanan gelişmeler devletlerin klasik diplomasi anlayışına farklı bir boyut kazandırmıştır. Kendini dış dünyaya daha iyi anlatabilme ve amaçlarını doğru bir şekilde aktarabilme ihtiyacı ülkelerin kamu diplomasisine daha fazla yoğunlaşmasını sağlamıştır. Son dönemde yükselen bir güç olarak ortaya çıkan Çin, kendisi ile ilgili endişeleri gidermek amacıyla kamu diplomasisi faaliyetlerini arttırmıştır.

Anahtar kelimeler: Kamu diplomasisi, yükselen güç, Çin, diplomasi, yumuşak güç

\begin{abstract}
Absract
Changes occuring over time have reverberated every field and diplomacy area as well. Especially techological developments have added distinctive dimension states' classical diplomacy apprehension. The necessity of explaining the states themselves better and citing their intentions truly have provided more attention on public diplomacy. China as a rising power recently is one of them having paid a lot of importence and stimulated its PD activities to relieve anxiety about herself.
\end{abstract}

Key words: Public diplomacy, rising power, China, diplomacy, soft power

\footnotetext{
${ }^{1}$ Yalova Üniversitesi İİBF Uluslararası İlişkiler Bölümü Araştırma Görevlisi.
} 


\section{Elif Sak}

\section{GíRiș}

Diplomasi, milletler arası münasebetlerin sürdürülmesi ve devletlerarasındaki anlaşmazlık ve çatışmaların devletlerin resmi organları ve görevlileri vasıtasıyla barışçıl yollarla çözüme kavuşturulmasını sağlayan en önemli araçlardan biridir. Diplomasinin bu anlamıyla kullanımı 17. ve 18. yüzyıllarda başlamış olsa da diplomasinin tarihi devletlerin tarihi kadar eskiye dayanmaktadır. "Nitekim diplomasinin ilk örneklerine vasallar, monarklar veya hükümdarlar arasındaki münasebetlerde rastlanmaktadır."2

Zaman içerisinde yaşanan değişim ve dönüşümler devletlerarasındaki münasebetleri ve buna bağlı olarak diplomasi yöntemlerini etkilemiştir ve günümüzde de etkilemeye devam etmektedir. Özellikle 20. yüzyılla birlikte siyasi, iktisadi, teknolojik ve sosyal alanlarda yaşanan gelişmelerin yeni gereksinimleri ortaya çıkarması diplomasi alanında devletlerin yeni arayışlar içine girmesine neden olmuştur .

20. yy’ de devletlerarasında klasik diplomasi faaliyetleri devam etmekle birlikte, bir devletin diğer devletlere ve/veya bu devletlerin halklarına kendisini en iyi şekilde ifade etme isteği kamu diplomasisinin ön plana çıkmasını sağlamıştır. Günümüzde birçok devlet kamu diplomasisi faaliyetlerinde bulunmaktadır, ancak yakın dönemde özellikle Çin'in bu alana yönelik çalışmalarında artış yaşanmıştır. Pekin'in kamu diplomasisi faaliyetlerine yoğunlaşmasının temelinde de ise çok kısa zamanda yükselen bir güç olarak ortaya çıkışı yer almaktadır.

1970'li yıllarda ekonomisinde “açık kapı politikası” $n ı$ benimseyen Çin, 20. yy' de kısa bir zaman içerisinde önemli bir ekonomik güç haline gelmiştir. Pekin'in yükselişi hem kendi coğrafyasında bulunan ülkelerin hem de ABD gibi küresel bir gücün dikkatini bu ülke üzerine yoğunlaştırmasına neden olmuştur. Nitekim coğrafi olarak yakın ülkeler bölgede Çin hakimiyetinin kurulmasından endișe duyarken, ABD de karşısında kendisine rakip olabilecek ve onunla "dünya liderliği" ni paylaşabilecek nitelikte bir devlet görmek istememektedir. Dolayısıyla Çin, diğer devletlerin bu endișelerini gidermek ve ülkenin gelişimine engel olmalarını önlemek amacıyla kamu diplomasisi faaliyetlerini yoğunlaştırmıştır.

Çin'in kamu diplomasisi üzerine yoğunlaşan bu çalışmanın birinci bölümünde genel olarak yumuşak gücün tanımına ve kaynaklarına yönelik açıklama yapılacaktır.

İkinci bölümde yumuşak gücün kullanımında kamu diplomasisinin yerine, araçlarına ve aktörlerine değinilecektir.

Üçüncü bölüm çerçevesinde yükselen gücün kamu diplomasisini şekillendiren faktörler, kamu diplomasisi faaliyetlerinde yer alan aktörler ve araçlar açıklanacaktır.

Dördüncü bölümde Çin'in yumuşak gücünün sınırları ifade edilmeye çalışılacak ve çalışma sonuç bölümü ile sonlandırılacaktır.

\section{YUMUŞAK GÜÇ}

Yumuşak güç kavramından ilk defa Joseph S. NYE' in 1990 yılında yayımlanan "Bound To Lead" adlı kitabında bahsedilmiştir. ${ }^{3}$ Soğuk Savaş sonrasında Nye tarafından ortaya atılan bu kavram, istediğini zor kullanmak veya para vermek yerine kendine çekme yoluyla elde etme becerisini ifade etmektedir. ${ }^{4}$ "Başkalarının tercihlerini şekillendirme yeteneğine dayanmakla birlikte, siyasi gündemi diğer insanların önceliklerini şekillendirecek tarzda tayin etme kabiliyetini de içinde barındırmaktadır. Daha çok tercihleri kabul ettirme becerisi, çekici bir karakter, kültür, siyasi değerler, kurumlar, meşru görülen ya da ahlaki otoritesi olan politikalar gibi soyut değerler ile ilgili bir kavramdır."

\footnotetext{
${ }^{2}$ Faruk Sönmezoğlu, Uluslar arası İlişsiler Sözlüğü, İstanbul Cem Yayınevi, 1992, S.107, Aktaran: Vedat

Demir, Kamu Diplomasisi ve Yumuşak Güç, Beta Yayınları, 2012, S.9

${ }^{3}$ Joseph S, Nye,(çev. Rayhan İnan Aydın) Yumuşak Güç, Elips Kitap, Ekim 2005, Birinci baskı, s.7

${ }^{4}$ Joseph S.Nye, a.g. e. , s.5

${ }^{5}$ J.S. Nye, Amerikan Gücünün Paradoksu. Gürol Koca ( terc.), İstanbul Literatür Yayıncıllk, 2003, s.11 Aktaran: Demir s.23
} 
Bir devlet başka devlet ya da devletlere çeşitli yollarla nüfuz edebilir. Bunun için sert güç kullanılabileceği gibi yumuşak gücün kullanılması da mümkündür. "Nitekim bir devlet dünya politikasında arzu ettiği sonuçlara havuçsopa yöntemini kullanarak ulaşabileceği gibi, başka devlet ya da devletlerin onun sistemini benimsemesi, onun değerlerlerine hayran olması, onun peşinden gitmek istemesi durumunda da ulaşabilir."6 Dolayısıyla Nye'a göre yumuşak güç işbirliğini zor kullanmaktan ziyade ortak değerler etrafında toplama ve bu değerlere katkıda bulunmayı sağlama yoluyla gerçekleştirmektedir. "Bu bağlamda açık bir tehdit veya değiş tokuş olmadan karşı tarafın amaçlarını kabul etmeye ikna olma söz konusudur."”

İkna etme ve insanları sözle değiştirme önemli unsurlar olmakla birlikte, yumuşak güç yalnızca bunlardan ibaret değildir. Aynı zamanda bünyesinde kendine çekme maharetini de bulundurması gerekir. "Dolayısıyla yumuşak güç davranışsal açıdan cezbedici edici gücü, kaynaklar açısından ise böylesine bir cazibeyi teşkil eden değerleri ifade etmektedir." ${ }^{\prime 8} \mathrm{Bu}$ değerler "bir ülkenin ve milletin tarihi ve kültürel bağları, ülke içinde ve dışında icra edilen politikalar ve milletler arası sahada kendini tanıtma tarzıyla" ortaya çıkmaktadır. ${ }^{9}$ Nye'a göre bir ülkenin yumuşak güç kaynakları konusunda 3 ana unsur vardır. Bunlar "kültür (başkalarına çekici geldiği yerlerde), siyasi değerler

görüldüğünde).”10

"Kültür, genel olarak bir toplum için anlam ifade eden değerlerin bütünüdür. Kültürün birçok görünüş şekli vardır. Genellikle seçkinlere hitap eden edebiyat, sanat ve eğitim gibi üst kültür ve eğlenceye dayalı popüler kültür olmak üzere ikiye ayrılır. Bir ülkenin kültürü evrensel değerler içerdiğinde ve politikalarının da paylaştığı değerlere ve menfaatlere hizmet etmesi durumunda meydana getirdiği sorumluluk ve cazibe sebebiyle istediği neticeleri elde etme ihtimalini arttırır." 11 "Nitekim Amerikan popüler kültüründe sık sık ifade edilen demokrasi, ferdi hürriyet, daha yüksek toplumsal seviyeye ulaşma ve aleniyet gibi değerler yüksek tahsil ve dış politika gibi sahalarda Amerikan gücüne büyük katkıda bulunmaktadır."12

Yumuşak gücün önemli kaynaklarından ikinci siyasi değerlerdir. Nye’a göre bir hükümetin yurt içindeki (mesela demokrasi), milletler arası kuruluşlardaki (diğerleriyle birlikte çalışan) ve dış politikadaki ( barışın ve insan haklarının gelişmesine yardımcı olan) tavrıyla sunduğu değerler başkalarının tercihlerini oldukça etkilemektedir. ${ }^{13}$ Dolayısıyla bir devletin demokratik bir yönetime sahip olması, düzgün işleyen bir hukuk sisteminin bulunması, kişilerin hak ve özgürlüklerine aynı derecede önem verilmesi ve başka ülkelere yardımda bulunması o ülkenin yumuşak gücünün artmasını sağlayacaktır.

Yumuşak gücün üçüncü önemli kaynağını oluşturan hükümet politikaları ve dış politika, başka devletler tarafından meşru ve ahlaki olarak görüldüğü ölçüde söz konusu devletin yumuşak gücüne katkıda bulunacaktır. ${ }^{14}$ Sadece ulusal menfaatlerin göz önünde tutulduğu ve diğer devletlerin çıkarlarının göz ardı edildiği, özellikle önemli karar alma yetkisine sahip uluslararası kuruluşlara üye olan ülkelerce benimsenen ve diğer devletler tarafından ikiyüzlü olarak algılanan politikaların yumuşak güce zarar verici etkisi olacaktır.

\section{YUMUŞAK GÜCÜN KULLANIMINDA KAMU DIPLLMASISİ}

Kamu diplomasisi kavramı ilk kez 1965 yılında Tufts Üniversitesi Fletcher Hukuk ve Diplomasi Okulu Dekanı Edmund Gullion tarafından kullanılmıştır. ${ }^{15}$ Üniversite'nin Edmund Murrow Kamu Diplomasisi Merkezi’nin ilk

\footnotetext{
${ }^{6}$ J.S. Nye, Bound to Lead: The Changing Nature of American Power. Newyork: Basic Books, 1990, s.31. Aktaran: Demir, a.g. e. ,s. 22

${ }^{7}$ Joseph S.Nye, a.g. e. , s.16

${ }^{8}$ Joseph S.Nye, a.g. e. ,s.15

${ }^{9}$ Vedat Demir, a.g. e. ,s.60

${ }^{10}$ J. S. Nye, a. g. e. ,s.20

11 J. S. Nye, a. g. e., s.20

${ }^{12}$ Vedat Demir, a.g.e. s.60

13 J. S. Nye, a.g.e., s. 23

14 J. S: Nye, a.g.e., s.22

15 J.N. Cull, Public Diplomacy: Lessons from the Past, Figueroa Press, 2009, Los Angeles, s.18
} 
zamanlarından bir broşürde kamu diplomasisi bilgi ve fikirlerin ulus ötesi akışı olarak değerlendirilerek aşağıdaki gibi tanımlanmıştır; ${ }^{16}$

"Kamu diplomasisi, dış politikaların düzenlenmesi ve yürütülmesi üzerindeki kamu tutumlarının etkilenmesini ele almaktadır. Geleneksel diplomasinin ötesindeki uluslar arası ilişkiler boyutlarını, hükümetlerin diğer devletlerdeki kamuoyu oluşturmalarını, özel grupların etkileşimini ve bir devletin ve bunların birbiriyle olan ilgi alanlarını, Dış işleri raporlarını ve bunların politikaya etkisini, işi iletişim olanlarla diplomatlarla ve dış temsilciler arasındaki iletişimi ve de kültürler arası iletişim sürecini kapsamaktadır.”

Edmun Gullion'ın ardından çeşitli meslekten insanlar kavrama ilişkin farklı tanımlamalarda bulunmuştur. Kamu diplomasisine ilişkin yapılan ilk tanımlarda amaçlar genellikle "hedef ülkelerdeki insanları etkilemek ve onların kendi hükümetlerini iç ve dış politikayı değiştirmesi için baskı altına alınmalarının sağlanması, dış politika amaçları ve ulusal çıkarları savunmak için yenilikçi bir çevre yaratmak amacıyla kamuoyunu oluşturmak" ${ }^{17}$ olarak belirlenmiştir. Bu amaçlar doğrultusunda geleneksel kamu diplomasisinin hükümetlerin küresel kamulara hitap etmesiyle ilgili olup bilgilendirme, etkileme ve bahsedilen kamuların ulusal amaç ve dış politikalara dahil edilmesi çabalarını içinde barındırdığı göze çarpmaktadır. ${ }^{18}$

İletişim teknolojisinde yaşanan gelişmelerle birlikte kamu diplomasisi faaliyetlerinin etkisi artmıştır. Teknolojide yaşanan gelişmeler devletler arasındaki coğrafi uzaklığı bir sorun olmaktan çıkarmış, dünya bir nevi küçük bir köy haline gelmiştir. Yaşanan gelişmeler sonucunda ortaya çıkan küreselleşme olgusuyla birlikte devletlerin birbiriyle ilgili bilgilere ulaşımı ve fikirlerin dolaşımı kolaylaşmıştır. Hükümet politikalarının ve faaliyetlerinin şekillenmesinde dünya kamuoyunun büyük bir öneme sahip olması devletlerin yabancı halkları etkileme konusunda kamu diplomasisini daha etkin bir şekilde kullanma ihtiyacını ortaya çıkarmıştır.

Küreselleşme devletler açısından bilgiye erişimi bir yandan kolaylaştırırken diğer yandan devletlerin bilgi akışını kontrol edebilme olanağını zayıflatmıștır. Nitekim "kitaplar, filmler, televizyon programları, internet ve tüketici ürünleri gibi milli devletlerin kontrolü dışındaki aktörler"19 bir ülke hakkında bilgi sahibi olma konusunda daha fazla rol üstlenmeye başlamıştır.

Geleneksel kamu diplomasisinden farklı olarak yabancı kamuoylarını etkilemede devletlerin dışında başka aktörlerin de rol üstlenmesi bazı akademisyenlerin yeni kamu diplomasisinden söz etmesine neden olmuştur. Cull yeni kamu diplomasisinde meydana gelen değişimleri şu şekilde sıralamaktadır: ${ }^{20}$

1. Milletler arası aktörler giderek geleneksel uygulamaların dışına çıkmakta ve bu sahada daha çok sivil toplum kuruluşları ön plana çıkmaktadır.

2. Dünya kamuoyuyla iletişim kurabilmek için bu aktörler tarafından kullanılan mekanizmalar yeni, gerçek zamanlı, küresel teknolojiler istikametinde yol almaktadır.

3. $\mathrm{Bu}$ yeni teknolojiler yerli ve milletler arası haber çevreleri arasında önceden mevcut olan katı çizgileri muğlaklaştırmaktadır.

4. Propagandanın eski konseptleri yerine kamu diplomasisi, bir tarafta pazarlamadan gelen özellikle mekan markalaşması ve milli markalaşma, diğer tarafta ağ iletişimi teorisinden gelişen konseptlerden gittikçe artan bir seviyede daha çok faydalanmaktadır.

5. Böylelikle itibar ve milletler arası imajın lisanı olarak kamu diplomasisinin yeni bir terminolojisi "yumuşak güç "ve markalaşma" nın dile getirilmesine yol açmaktadır.

6. Yeni kamu diplomasisi, Soğuk Savaş döneminin "aktörden insana” iletişiminde bir kopuş ve kolaylaştırıcı rolü oynayan milletler arası aktörler ile birlikte aydınlanma için "insandan insana” yeni bir ilişkiye vurgunun gelişiminden bahsetmektedir.

\footnotetext{
${ }^{16}$ Gaye Aslı Sancar, Kamu Diplomasisi ve Halkla İlişkiler, Beta Yayınları, Temmuz 2012, İstanbul, Birinci basım, s.79

${ }^{17}$ Gaye Asli Sancar, a.g.e. ,s.82

${ }^{18}$ Nancy Snow, Persuader-in-chief: Global Opinion and Public Diplomacyin the Age of Obama, Nimble Books, 2009, s.6

${ }^{19}$ Vedat Demir, a.g.e., s.17

${ }^{20}$ N.J. Cull, a.g.e. , s. 12-13, Aktaran: Demir , s. 17
}

BARIŞ ARAŞTIRMALARI VE ÇATIŞMA ÇÖZÜMLERİ DERGİSİ http://dergi.cicr.org.tr/ 
7. Yeni kamu diplomasisinin asli görevi "münasebet tesis etme" olarak belirlenmiştir. Ancak bu modelde de temel amaç milletler arası zeminin idaresi olarak belirlenmektedir.

Cull yeni kamu diplomasisinin esası ile "yumuşak güç" arasındaki ilişkiyi de şu şekilde açıklamaktadır: ${ }^{21}$ "Yumuşak güç aynı zamanda kamu diplomasisi anlamına gelmemektedir. Kamu diplomasisi yumuşak gücün dağıtılmasında yalnızca bir araç olabilir. Nitekim bir devlet yumuşak güç unsurlarına sahip olsa da kamu diplomasisi faaliyetlerinde bulunmayabilir ya da kamu diplomasisi faaliyetleri yürüten bir ülke yumuşak güç unsurlarına sahip olmayabilir."

Yeni kamu diplomasisinin nihai amacı geleneksel kamu diplomasisi ile aynı olmakla birlikte, özellikle teknolojide meydana gelen değişimler kamu diplomasisinin kullanıldığı alanlarda ve kamu diplomasisi faaliyetleri içinde yer alan aktörlerde değişiklere yol açmıştır. Geleneksel kamu diplomasisinde faaliyetler daha çok kısa dalgalı radyo yayınları, sabit hatlı telefonlar ve yazılı basın üzerinden yürütülürken yeni kamu diplomasisinde bunların yerini uydu, internet, gerçek zamanlı haberler ve mobil telefonlar almıştır. Aktörler bazında geleneksel diplomasi faaliyetleri yalnızca devletler tarafindan icra edilirken, yeni kamu diplomasisinde devletlerin yanında devlet dışındaki aktörler de bu faaliyetler içinde yer almaktadır.

Kamu diplomasisinin devlet dışındaki aktörlerini 8 başlık altında incelemek mümkündür: ${ }^{22}$

Sivil Toplum Kuruluşları, "genel olarak yurttaşların ortak bakış, ortak çıkar, ortak duyarlılık, ortak talep gibi temeller üzerinde gönüllü olarak bir araya gelmesi”’23 olarak tanımlanmaktadır. "Bu kuruluşlar devletin hukuki, ticari, idari ve kültürel organlarının dışındaki alanda meydana getirdikleri dernek, vakıf, sivil girişim, platform, ilişki ağı ve benzerlerinden oluşan yapıları ve etkinlikleri kapsamaktadır." ${ }^{24}$ Sivil toplum kuruluşları aynı zamanda üçüncü sektör ya da hükümet dışı organizasyonlar olarak da adlandırılmaktadır. ${ }^{25}$

"Katılımcı demokratik yapı ve çoğulcu bir toplumun oluşmasına katkıda bulunan sivil toplum kuruluşları, bugün modern toplumların en etkin siyasi baskı ve toplumsal değişim aktörleri arasında bulunmakta ve ülkelerin kamu diplomasisi faaliyetlerinde yer almaktadır."26 Özellikle yeni teknolojileri faal bir biçimde kullanması ve basın toplantıları, televizyon haberleri, cep telefonları ve internet vasıtasıyla eylemlerini doğrudan kamuoyuna ulaştırabilmeleri sivil toplum kuruluşlarının yeni kamu diplomasisinde, devletlerin yanında önemli bir aktör olarak yer almasını sağlamaktadır. ${ }^{27}$

"Sivil toplum kuruluşları milletler arası politikada iki tür rol üstlenmektedir. Bir bölümü hükümetlerin ortakları olarak hükümet politikalarını desteklemekte ve katkı sunmaktadır. Diğer bölümü ise devletlerden bağımsız hareket etmektedir." ${ }^{28}$ Dolayısıyla kamu diplomasisi faaliyetlerinden daha fazla olumlu sonuç elde edebilmek için devletlerin öncelikle gerçekleştirilen faaliyetler çerçevesinde sivil toplum örgütlerini desteklemesi gerekmektedir. "Sesini dışarıda duyurmak ve dışarıdaki olayların kontrolünü ele almak isteyen bir ülkenin, devletten ayrı, müstakil ve devletle kültürel bağlantısı muğlak müessese ve organizasyonlar vasitasıyla faaliyetlerde bulunması kamu

\footnotetext{
${ }^{21}$ N.J. Cull, a.g.e., s. 15

${ }^{22}$ Gaye Asli Sancar, a.g.e., s. 91-108

${ }^{23}$ Aydın Uğur," Yeni Demokrasinin Yeni Aktörleri; STK'lar”, Der. Tacisel Ulaş, İstanbul, Helsinki Yurttaşlar Derneği Yayın Dizisi, 10, 1998. Aktaran: Emine Akçadağ, “Avrupa Birliği Sürecinde Kamu Diplomasisi Faaliyetlerinde Sivil Toplum Kuruluşlarının Rolü’, s.1, www.kamudiplomasisi.org/pdf/siviltoplumkuruluslari.pdf ( Erişim tarihi: 3 Haziran 2013)

${ }^{24}$ Fatih Duman, Sivil Toplum, Siyaset, Lotus yayınevi, İstanbul, Eylül 2003, s.365. Aktaran: ${ }^{24}$ Emine Akçadağ, “Avrupa Birliği Sürecinde Kamu Diplomasisi Faaliyetlerinde Sivil Toplum Kuruluşlarının Rolü”, s.1, www.kamudiplomasisi.org/pdf/siviltoplumkuruluslari.pdf ( erişim tarihi: 3 Haziran 2013)

${ }^{25}$ Emine Akçadağ, “Avrupa Birliği Sürecinde Kamu Diplomasisi Faaliyetlerinde Sivil Toplum Kuruluşlarının

Rolü”, s.1, www.kamudiplomasisi.org/pdf/siviltoplumkuruluslari.pdf (erişim tarihi: 3 Haziran 2013)

${ }^{26}$ Emine Akçadağ, a.gm., s.1

${ }^{27}$ H. Tuncer, Diplomasinin Evrimi, Gizli Diplomasiden Küresel Diplomasiye, 2009, Kaynak Yayınları, İstanbul, s.214, Aktaran: Demir s.66

${ }^{28}$ H. Tuncer, s.214, Aktaran: Demir, s.66
} 
diplomasisi faaliyetlerinin olumlu sonuçlar vermesi açısından önemlidir.” ${ }^{29}$ Bununla birlikte sivil toplum kuruluşları hedef olarak belirlenen devlet dışında hükümet dışı aktörlerle çalışma, dışarıdaki sivil toplum örgütleriyle iletişim kurma konusunda da kamu diplomasisi çerçevesinde önem taşımaktadır. Çünkü her birinin kendi uzmanlık alanının var olması ve bu alanda bağımsız hareket etmeleri daha geniş çaplı faaliyetlerde bulunmalarına imkan sağlamaktadır. STK'ların kamu diplomasisi alanında sahip olduğu bir diğer avantaj ise yabancı devletler tarafından kolay bir şekilde elde edilemeyen "itimat, uzmanlık ve uygun araçlar" 30 olmak üzere üç önemli kaynağa sahip olmalarıdır.

Geleneksel kamu diplomasisinde olduğu gibi yeni kamu diplomasisinin temel aktörü de devletlerdir. Ancak çok sayıda sivil toplum kuruluşunun var olması ve bunların devletin nüfuz edemediği alanlarda faaliyetlerde bulunması STK' ların devletlerin yanında önemli bir aktör olarak ortaya çıkışına zemin hazırlamıştır.

Üniversiteler ve Okullar kamu diplomasisi sürecinde özellikle kültürel diplomasi yönüyle ön plana çıkmaktadır. "Üniversiteler daha çok kültürel diplomasi uygulamaları bakımından etkili olmakla birlikte, okullar genellikle bulundukları ülkenin vatandaşlarına kültürel değerlerin aktarılmasını sağlamaktadır." 31 Özellikle yabancı ülkelerde kurulan üniversiteler ülkenin kültürünün ve değerlerinin tanıtılmasında önemli rol oynamakta, genel olarak ise üniversiteler bünyesinde gerçekleştirilen değişim programları, konferans, kongre gibi çeşitli vasıtalarla ülkenin iletmek istediği mesaj aktarılmaktadır.

Kanaat Önderleri, mesajların iletilmesi sürecinde güvenilir bilgi kaynağı olarak görüldüklerinden dolayı kamu diplomasisinin önemli aktörlerinden biridir. "Bir ülkenin sahip olduğu kanaat önderleri, ödüllü sanatçıları, edebiyatçıları o ülkenin yumuşak güç kaynakları arasında yer almaktadır." 32 Bu alanlarda ödül alan kişiler sayesinde ülkeler kendilerini dış dünyada daha fazla tanıtma imkanı bulmakta ve bu kişiler kamu diplomasisi mesajlarının iletilmesinde önemli bir kanaat önderi olarak ortaya çıkmaktadır.

$\dot{I}_{c ̧}$ Hedef Kitle, "kamu diplomasisinde sosyal paydaş olarak ele alınmaktadır. Dışarıdaki başarıdan önce içerideki istikrarın sağlanması ve dünyaya aktarılması gibi bir görevin gerçekleştirilmesinde önemli bir aktör olarak yer almaktadır."33

Bir devletin kendi iç hedef kitlesine olan yaklaşımı, dışarıdaki hedefe gönderilen mesajın algılanmasında önem taşımaktadır. ${ }^{34}$ Örneğin bir ülkenin kendi vatandaşlarına yönelik davranışları, insan hakları ihlallerinin gerçekleşmesi, insan haklarına yönelik kısıtlamaların yapılması o ülkenin dışarıda imajının zedelenmesine neden olacaktır. Dolayısıyla bir devlet uluslar arası alanda iletmek istediği mesaja yönelik olarak ilk önce kendi vatandaşlarının desteğini sağlamalıdır. Nitekim vatandaşlar kendi ülkeleri ile ilgili mesajların iletilmesinde yurttaş diplomasisi aracılı̆̆ıyla önemli rol oynamaktadır.

Medya ve Haber Ajansları, kamu diplomasisi faaliyetlerinde yaygın olarak kullanılan ve yabancı kamuoylarını etkileme ve gündem oluşturma konusunda en etkili olan araçtır. Bu nedenle gelişen teknoloji ile birlikte bilginin hızlı bir şekilde dağılımı ve yönetimi sürecinde medya, devletler açısından daha fazla önem taşımaya başlamıştır. "Nitekim devletler hakkında bilgi aktarımı konusunda birincil kaynak niteliğinde olan birçok devletin elçiliğinde, özellikle “ABD, İngiltere ve Fransa gibi büyük ülkelerde, uluslar arası alanda ülke hakkında olumlu imajın yerleşmesini sağlamak amacıyla kurulan basın ateşeleri” ${ }^{35}$ vardır.

\footnotetext{
${ }^{29}$ M. Leonard, C. Stead, C. Smewing, Public Diplomacy, 2002, London, Foreign Policy Center, s. 55-56, Aktaran : Demir, s.66

30 M. Leonard, C. Stead, C. Smewing, Public Diplomacy, 2002, London, Foreign Policy Center, s.56, Aktaran , Demir, 66

${ }^{31}$ G. A. Sancar, a.g.e. , s.92

${ }^{32}$ G.A.Sancar, a.g.e., s.94

${ }^{33}$ G.A. Sancar, a.g.e. , s.96

${ }^{34}$ Micheal Kunczik, Images of Nations and International Public Relations Lawrence Erlbaum, New Jersey, 1997. Aktaran. Sancar, s.98.

${ }^{35}$ Michael Kunczik, Images of Nations an International Public Relations, Lawrence Erlbaum, New Jersey, 1997, s. 62, Aktaran: Sancar, s. 99
} 
Bir ülkenin içeriden dışarıya doğru gerçekleştirdiği faaliyetlerin yanı sıra yabancı basında çıkan haberler de uluslar arası toplumun söz konusu ülke ile ilgili fikrinin şekillenmesinde önemli rol oynamaktadır. Bu bağlamda kamu diplomasisi sürecinde gerçekleştirilen medya faaliyetlerinin bir kısmını yabanı basının yönetimi oluşturmaktadır. Bunun etkili bir şekilde gerçekleştirilebilmesi amacıyla da diğer ülkelerdeki medya ile ilişki içerisinde bulunmak büyük önem taşımaktadır. Dolayısıyla medya faaliyetlerinin hem içsel hem dişsal boyutunun var olması, geniş bir kitleye hitap etme olanağına sahip olması ve bilginin hızlı bir şekilde aktarımını gerçekleştirmesi medyanın bu süreçte en önemli aktörlerden biri olarak konumlanmasını sağlamaktadır.

Özel Sektör ve Küresel İşletmeler, yoğun bir şekilde kamu diplomasisi faaliyetleri yürüten aktörler arasında yer almaktadır. Şirketlerin kamu diplomasisinde önemli bir aktör haline gelmesi "kurumsal kamu diplomasisi” olarak da ifade edilmektedir. Kurumsal diplomasi ile asıl olarak kurumsal ilişkilerin meydana geldiği çevrenin paylaşılması suretiyle müşteriler ile ilişkileri karmaşık hale getiren yanlış anlaşılmaları ortadan kaldırma amaçlanmaktadır. ${ }^{36}$ Bununla birlikte küresel ölçekteki şirketlerin müşterileri ile olan ilişkileri vasıtasıyla kurum kültürünü ve kurumun kökeninin dayandığı ülkeyi anlatma imkanı da ortaya çıkmaktadır. Dolayısıyla devletlerin ticari ilişkileri boyutunda küresel şirketler hedef olarak seçilen ülkede kamu diplomasisi faaliyetleri yürütme konusunda etkili bir devlet dışı aktör olarak rol oynamaktadır.

Kamu diplomasisi faaliyetlerinde özel işletmelerin bir aktör olarak yer alması çeşitli avantajları beraberinde getirmektedir. Örneğin iletilmek istenen mesaj farklı şekillerde hedef kitleye ulaştırılmakta ve hükümetlerin de bu alanda yaptığı harcamalar azalmaktadır.

Devlet Üstü Kuruluşlar, kamu diplomasisi sürecinde diğer aktörlerden daha farklı rol üstelenmektedir. "Bu tür kuruluşlar bazı durumlarda devletlerin eylemlerini sınırlamakla birlikte aynı zamanda hükümetlerin stratejilerinin doğrulanması ve eylemlerine meşruiyet kazandırılması açısından önem taşımaktadır." 37 "Bununla birlikte devlet üstü kuruluşlar devletlerin dış politikalarının zemini olarak da kullanılabilmektedir”. Nitekim bir devlet herhangi bir konuda sert güce başvurduğunda bu durumu içinde yer aldığı uluslar arası örgüt çerçevesinde ifade ederek kendisi üzerinde meydana gelecek etkiyi azaltmaktadır. ${ }^{38}$

Baskı Grupları, "belli bir amacı gerçekleştirmek amacıyla oluşan, hükümeti ve resmi organları çıkarları lehine etkilemeyi hedefleyen ve bunun için çalışan topluluklardır. En önemli özellikleri isteklerini siyasal iktidar amacı gütmeden siyasal iktidarı etkileyerek elde etmeye çalışmalarıdır."39 " Çoğu zaman bir tek konu etrafında bir araya gelirler ve hukuki yapıları mevcut değildir. Amaçlarına ulaşmak ve kamuoyuna, devlet ve hükümet kurum ve kuruluşlarına seslerini duyurmak için çeşitli iletişim yöntemlerinden yararlanırlar." 40 "Modern toplumlarda işveren birlikleri ( ticaret odaları, işveren sendikaları, büyük şirketler, holdingler) işçi kuruluşları (sendikalar, sendika konfederasyonları) ve çeşitli dernekler gibi birçok baskı grubu yer almaktadır."

Kamu diplomasisi bir ülkenin kendisini uluslar arası arenada en iyi şekilde açıklamasına yönelik faaliyetleri içinde barındırmaktadır. Nitekim gerçekleştirilmek istenen ülkenin kültürünü, değerlerini, içerideki ve dışarıdaki politikalarını en iyi şekilde yabancı kamuoyuna aktarmaktır. Dolayısıyla bir ülkenin kendini en iyi şekilde tanıtabilmesi mümkün olduğunca çok alanda gerçekleştirilebilecek faaliyetlerle mümkün olmaktadır.

Devletler kamu diplomasisinin hala en önemli aktörleri konumundadır. Ancak özellikle iletişim teknolojisinde yaşanan gelişmeler sonucunda yeni kamu diplomasisi anlayışının yerleşmesiyle birlikte devletlerin yanında başka aktörler de kamu diplomasisi sürecinde yer almaya başlamıştır. Bu şekilde hem devletin üzerindeki mali yük

\footnotetext{
${ }^{36}$ Mark Drapeau, “Corporate Public Diplomacy: Engaging and İmproving Stakeholder Communities” Public Diplomacy Magazine. http:// publicdiplomacymagazine.com/something-to-believe-in/ Erişim tarihi: 4 Haziran 2013

${ }^{37}$ G. A. Sancar, a.g.e., s. 106

${ }^{38}$ Faruk Sönmezoğlu, Uluslar arası Politika ve Dış Politika Analizi, Filiz Kitabevi, 3. Baskı, İstanbul, 2000, s.652, Aktaran: Sancar, s.106.

${ }^{39}$ G. A. Sancar, a.g.e., s. 107

${ }^{40}$ Aysel Aziz, Siyasal İletişim, Nobel Yayın Dağıtım, Ankara, 2003, s.23. Aktaran: Sancar, s.108

${ }^{41}$ Arsev Bektaş, Kamuoyu, İletişim ve Demokrasi. 2. Basım İstanbul, Bağlam Yayınları, 2000, s. 42-43, Aktaran: Sancar s.107
} 
azalmış hem de devletin erişemediği yerlerde çeşitli uzmanlık alanlarına sahip aktörlerin faaliyet gösterme olanağ ortaya çıkmıştır. Bu durum da beraberinde uluslar arası alanda devletlerin çok yönlü olarak tanınmasına imkan sağlamıştır.

\section{YÜKSELEN GÜÇ ÇINN VE KAMU DİPLOMASİSI}

Küreselleşme geleneksel diplomasi yöntemlerinin yanı sıra kamu diplomasisinin de gelişimine zemin hazırlamıştır. Yaşanan gelişmelere bağlı olarak bilginin hızlı dolaşımı devletlerin dışarıda kendilerini en doğru şekilde ifade edebilme ve yabancı kamuoyunun desteğini alma ihtiyacını ortaya çıkarmıştır. Özellikle son dönemlerde Çin'in yükselen bir güç olarak ortaya çıkması ve bu durumun uluslar arası arenada devletler tarafindan farklı yorumlanması ülkede kamu diplomasisi faaliyetlerinin daha fazla yoğunlaşmasını sağlamıştır.

\section{Çin'de Kamu Diplomasisinin Tarihi Gelişimi}

Çin, özellikle son dönemlerde kamu diplomasisi faaliyetlerini arttırmış olsa da aslında bu tür faaliyetlerin kökleri Çin'de çok eskiye dayanmaktadır. Örneğin Tang Hanedanlığı döneminde Çin sınırlarını tehdit eden düşmanlarla ittifak kurmak amacıyla gönderilen Çinli prensesler "diplomat gelinler" 42 olarak adlandırılmaktadır. Nitekim gönderilen bu prensesler sayesinde hem barış sağlanmış hem de kurulan ittifakın sonucunda ticari ilişkiler gelişme göstermiştir. Ayrıca prenseslerle birlikte giden eşyalar, kitaplar, yemekler vasıtasıyla ülkeler arasında kültürel etkileşim de başlamıştır.

Hanedanlık döneminde kamu diplomasisi faaliyetlerinin bir kısmı da ülkeye gelen misafirler aracılığıyla gerçekleştirilmiştir. ${ }^{43}$ Ülkeyi ziyarete gelenler, misafirlere gösterilen ilginin Çin açısından olumlu sonuçlar vereceği inancıyla Çin medeniyetinin ve kültürünün zenginlikleriyle kuşatılmıştır. İzleyen yılarda da, bu düşünceyi destekler bir biçimde, Batı Çin kültürünü kendisine uyarlamıştır. 17. ve 18. yy boyunca Avrupa'da Çin kültürü moda haline gelmiştir. Ancak bu durum Çin'in çıkarları doğrultusunda desteklenmediği için kamu diplomasisindeki rolü kısıtlı kalmış, politik söylemler ve ortaya çıkan karmaşık kültür uluslar arası toplumun dikkatini Çin üzerine yoğunlaştırmasına neden olmuştur. ${ }^{44}$

Çin'in kamu diplomasisi faaliyetleri 1949'da Komünist Parti'nin iktidar olmasıyla artış göstermiştir, ancak öncesinde de Komintag Hükümeti'ne karşı destek bulabilmek için birtakım faaliyetler gerçekleştirilmiştir. Bu çabalar tam olarak kamu diplomasisi olarak adlandırılamasa da Komünist Parti bu faaliyetleri ile Komintag Hükümeti'ni hem yerel hem de uluslar arası destekten yoksun bırakmayı amaçlamıştır. ${ }^{45} 1935$ yılında Japonya'nın Çin'i istilasına engel olmak amacıyla partilerin birbiriyle savaşmaktan vazgeçmesi ve Japonya'ya karşı “Ulusal Savunma Hükümeti” kurulması için Komünist Parti çağrıda bulunmuştur. O dönemde Komintag Hükümeti'nin de davete olumlu cevap vermesi 7 Temmuz 1937 yılında Çin ve Japonya arasında savaş çıktığında partilerin Japonya'ya karşı ortak bir duruş sergilemesini sağlamıştır. Böylelikle Komünist Parti hem Komintag Hükümeti’ni düşürme niyetini gizlemeyi başarmış hem de kırsal alandaki toprakların koruyuculuğunu yaparak uluslar arası toplumun sempatisini ve desteğini kazanmayı başarmıştır. ${ }^{46}$

Komintag Hükümeti döneminde Komünist Parti’nin uluslar arası toplumun dikkatini çekmesini sağlayan bir diğer unsur Amerikalı gazeteci Edgar Snow'un Yenan'1 ziyaret etmesi olmuştur. ${ }^{47}$ Snow, bölgeye gitmesinin ardından burada parti’nin hem Japonya istilasına hem de Komintag Hükümeti’nin baskılarına karşı çabalarını anlatan “ Red Star Over China" adlı kitabını yazmıştır. Kitabın yanında bu konularda çeşitli makalelerin yayınlanması ve Çin

\footnotetext{
${ }^{42}$ Hessarbani Anja Lejli, Public Diplomacy of Peopşe's Republic of China, Sarajevo, 2011 s.5

${ }^{43}$ Gary D. Rawnsley, China Talks Back, s.284

${ }^{44}$ Gary D. Rawnsley, a.g.e., s. 284

${ }^{45}$ Ming Lee, Chaina's Public Diplomacy: A Useful Smart Power, Ar1 Working Paper Series No.10, November 2009, s.6

${ }^{46}$ Ming Lee, Chaina's Public Diplomacy: A Useful Smart Power, Ar1 Working Paper Series No.10, November 2009, s.6

${ }^{47}$ Hessarbani Anja Lejli, a.g.m., s.4
} 
Halk Cumhuriyeti'nin kurulmasının ardından tekrar ziyaretlerin gerçekleştirilmesi, Edgar Snow’un da Komünistlerin desteğini almasını sağlamıştır. Gerçekleştirilen bu faaliyetler neticesinde de Komünist Parti Amerika'ya karşı düşmanca bir tutum içerisinde olmadığı yönünde açıklamalarda bulunmuştur. Resmi bir kanal veya köprü olarak Amerikalı gazeteci gelecekte iki ülke arasındaki ilişkilerin normalleşmesi sürecinde önemli bir rol oynamıştır. ${ }^{48}$

1938 yılında Kanadalı Fizikçi Dr. Henry Norman Bethune’ın Komünist Parti’nin sağlık servisine yardım etme amacıyla Yenan'a gelmesi Kanada ile Çin arasındaki ilişkilerin gelişmesine zemin hazırlamıştır. 1939 yılında Mao Zedong Dr. Bethune'ın anısına bir makale yayınlamış ve 1964 yılında da Bethune'ı konu edinen bir film çekilmiştir. ${ }^{49}$ Kanada da Çin'in bu konudaki duyarlılığına kayıtsız kalmayarak 1976 yılında Çin ile diplomatik ilişkilerini geliştirmeye yönelik faaliyetler içerisinde bulunmuştur.

1949 yılında Mao’nun iktidara gelmesiyle birlikte diplomasiden daha çok propaganda teknikleri kullanılmıştır. Ülkede hem yabancılar hem de vatandaşlar açısından bilgiye erişim konusunda sınırlamalar getirilmiştir. Ayrıca belirli gazetecilerin ülkeye girişine izin verilmiş, “Bejing Review” gibi devlet destekli gazeteler de yalnızca Çin'in başarılarından bahsetmiştir. Uluslar arası alanda daha çok Tayvan'ın zayıflatılmasına yönelik kampanyalar yürütülmüştür. Bununla birlikte ilk olarak Doğu Asya'da olmak üzere daha sonra Latin Amerika ve Afrika'da yer alan ülkelerde yapılması planlanan reformlar için çeşitli aktiviteler düzenlenmiştir. ${ }^{50}$

1966 yılında başlayan “Kültürel Devrim” ülke içinde karışıklığın artmasına neden olmuştur. Yaşanan olaylara rağmen Mao, Amerikan karşıtı olan politikasını 1968 yılına kadar değiştirmemiştir. Çin'in dış politikasını yeniden şekillendiren olay ise Sovyetler Birliği ile Kuzey Mançurya'da yaşanan sınır çatışması olmuştur. Bu olaydan sonra Çin, Moskova’yı kendisi için en tehlikeli ülke olarak görmeye başlamıştır. Hem ABD hem de Sovyetler Birliği’ne aynı anda karşı duracak kadar güçlü olmadığından ABD ile ilişkilerini normalleştirme kararı almıştır. Bu süreç Çin'in kamu diplomasisi faaliyetlerine tekrar yoğunlaşması için zemin hazırlamıştır. ${ }^{51} \mathrm{Bu}$ çerçevede Çin, 1971 yılında Amerikan masa tenisi takımını ve birkaç gazeteciyi ülkesine davet etmiştir. Bu davetin ardından Çin masa tenisi takımı da Amerika'yı ziyaret etmiştir. Washingon ve Pekin asındaki ilişkilerin geliştirilmesine yardımcı olan bu karş1lıklı ziyaretler "Ping- Pong Diplomacy" olarak bilinmektedir. ${ }^{52}$

Devrim diplomasisinin ortaya çıkardığı engellerden sonra yeni bir diplomasi arayışı başlamıştır. Kültürel Devrim sırasında uzaklaştırılan Den Xiaoping 1970'lerin başında geri dönmüştür. Altıncısı düzenlenen BM Genel Kurul Toplantısı'nda "Üç Dünya” düzeni üzerine kurulan teoriden bahsetmiştir. Küresel politikada üç dünya düzeni bulunduğunu ve kendisinin de üçüncü dünya ülkeleri arasında yer aldığını belirtmiştir. Birinci dünya ülkelerini yalnızca ABD ve Sovyetler Biriliği’nin, ikinci dünyayı zengin ülkelerin ve üçüncü dünyayı ise Asya, Afrika ve Latin Amerika'da yer alan gelişmemiş veya gelişmekte olan ülkelerin oluşturduğunu dile getirmiştir. Bu teori çerçevesinde Çin'in üçüncü dünya ülkeleri ile benzer sıkıntılarının olduğunu, bu nedenle birinci ve ikinci dünya içerisinde yer alan ülkelerin tehditlerine karşı onların yanında yer alacağını bildirmiştir. ${ }^{53}$ Bu söylemler üçüncü dünya ülkelerinin güvenini ve desteğini kazanmada etkili olmuş, Pekin de bu grupta yer alan ülkelerin temsilcisi olarak uluslararası alanda kendisini ifade etme fırsatını yakalamıştır.

1970’lerin başında Tanzanya'ya demiryolu yapımı için dış yardımda bulunulması Çin'in Afrika ülkelerinin diplomatik desteğini almasında etkili olmuştur. Ayrıca Afrika ülkelerinde çalışan mühendisler aracılığıyla da Üçüncü Dünya ile önemli dostluklar tesis edilmiştir. ${ }^{54}$ Bunlara ek olarak Çin, dışarıda gerçekleştirdiği bu tür faaliyetlerden bahseden "China Reconstructs, China Pictorial, Beijing Review" 55 gibi dergiler çıkarmaya başlamıştır. Bu dergilerin geniş alanda dolaşımı "Barışsever Ülke" imajı oluşturmayı kolaylaşmıştır.

\footnotetext{
${ }^{48}$ Ming Lee, a.g.m., s.7

49 Ming Lee, a.g.m. ,s.7

${ }^{50}$ Monroe E. Price, Daniel Dayan, Owning the Olympics: Narratives of the New China, s.127

${ }^{51}$ Ming Lee, a.g.m., s.9

${ }^{52}$ Hessarbani Anja Lejli, a.g.m., s.4

53 Ming Lee, a.g.m. , s.9

${ }^{54}$ Ming Lee, a.g.m., s.9

${ }^{55}$ Ming Lee, a.g.m. , s.10
} 
1979 yıllarında Mao’nun ardından Den Xaioping’in ülkenin başına geçmesiyle birlikte ülkenin iç politikasında büyük değişim yaşanmıştır. "İlk olarak ülke ekonomisinin düzeltilmesi amaçlanmıştır. Açık kapı politikası benimsenmiş, özel sektörün korunmasına önem verilmiş ve kıyı şehirlerinde ekonomik bölgelerin oluşturulmasına özen gösterilmiştir. Yaklaşık on yıl sonra meydan gelen ekonomik gelişmeyle birlikte gelen politik istikrar Çin vatandaşlarını memnun etmiştir." 56 Ancak aynı dönemde ortaya çıkan yolsuzluklar sosyal rahatsızlıklara yol açmıştır. Temmuz 1989'da Tiannanmen Meydanı'nda genç öğrenciler ve sivil vatandaşlar ayaklanma başlatmıştır. Çin Hükümetinin burada kendi vatandaşlarına sert güç kullanarak müdahale etmesi ve olayların kanlı boyuta ulaşması benimsenen reform politikası sonucunda o zamana kadar oluşan Çin hakkındaki olumlu imajın sarsılmasına neden oluştur. Çin, bu olay nedeniyle kendisi hakkında dişarıda ortaya çıkan ve yabancı medya tarafından dile getirilen olumsuz ifadelerle başlangıçta ilgilenmemiş, ancak daha sonra izolasyon politikasından vazgeçmenin gerekliliğini anlayarak imajını düzeltebilmek için dünyanın en büyük halkla ilişkiler firmalarından biri olan Hill \& Knowlton'1 kiralamıştır. ${ }^{57}$ Dolayısıyla Tiannanmen Olayı ve uluslar arası alanda bu konuyla ilgili Çin’e ilişkin olumsuz söylemlerin artması ülkenin kamu diplomasisi faaliyetlerini arttırmasında etkili olmuştur.

\section{Yeni Dönemde Çin’in Kamu Diplomasisi}

Çin uzun yıllar kapalı bir toplum olarak varlığını sürdürse de aslında her zaman dış dünya ile iletişim halinde olmuş ve diğer devletlerle işbirliği yapabilmek ve dünya barışını korumak için çaba harcamıştır. O dönemlerde yürütülen faaliyetler açısından tam olarak kamu diplomasisi terimi kullanılamasa da yine uluslar arası alanda kendi amaçlarını ve niyetlerini en doğru şekilde aktarma ve yabancı kamuoyunun desteğini kazanma amaçlanmıştır. Ülkenin iç politikası zaman zaman değişse de dış politika hedefleri açısından çok fazla değişim yaşanmamıştır. Önceden olduğu gibi yine temelde "gelişmekte olan ülkelerle dayanışmanın güçlendirilmesi ve emperyalizim ile kolonyalizme karşı durma, ortak bir ilerleme sağlayabilmek için gelişmiş ülkelerle ilişkileri geliştirme, Çin'in bütünlüğünü sağlama ve yine dünya barışını koruma” amaçlanmıştır. ${ }^{58}$ Ancak kısa zamanda Çin'in ekonomik bir güç olarak ortaya çıkması uluslar arası toplumun dikkatini Çin üzerine toplamış, bu durum da Çin'in dış politikaya yönelik faaliyetlere daha fazla önem vermesine neden olmuştur. Yükselişinin herhangi bir devlet için tehdit oluşturmadığını belirtmek, amaçlarını doğru ifade etmek ve dünyaya kendisini en iyi şekilde anlatabilmek için gelişimine paralel olarak kamu diplomasisi faaliyetlerini de arttırmıştır.

Çin'in Kamu Diplomasisi faaliyetleri ile gerçekleştirmek istediği amaçları 4 ana başlık altında toplamak mümkündür: ${ }^{59}$

1. Kendi vatandaşlarına daha iyi bir gelecek sunmak ve politik sisteminin ve politikalarının doğru bir şekilde anlaşılmasını sağlamak

2. Korkulan bir ekonomik güç gibi görünmek yerine, güvenilir, istikrarlı ve sorumluluk alabilen bir ekonomik ortak olarak görünmek

3. Uluslar arası toplumda sorumluluk sahibi olarak görünmek ve dünya barışına aktif olarak katılımı sağlamak

4. Uzun tarihine ve eski kültürüne saygı duyulmasını sağlamak

Çin'in bu hedeflere yönelik yürüttüğü kamu diplomasisi faaliyetlerinin temelini oluşturan yumuşak güç kaynakları ise Nye'ın yaptığı sınıflandırmaya göre 3 başlık şeklinde belirtilebilir. Bunlar “ Pekin Konsensüsü” ve Çin gelişme modeli, dış politikada barışçıl yükseliş ve barışçıl gelişme söylemi ve uzun tarihi ile Çin uygarlığıdır. ${ }^{60}$ Bunlara ek olarak Çin'in yumuşak gücüne katkıda bulunan diğer unsurlar arasında diğer bölgelere yapılan yatırımlar,

\footnotetext{
${ }^{56}$ Ming Lee, a.g.m. , s.10

${ }^{57}$ Hessarbani Anja, a.g.m., s. 4

${ }^{58}$ Hessarbani Anja, a.g.m. s. 4

${ }^{59}$ Hessarbani Anja, a.g.m., 5

${ }^{60}$ Young Nam Cho, Jong Ho Jeong, China's Soft Power: Discussions, Resources and Prospercts, Asian Survey, Vol 48, No 3(May/June 2008)s. 461
} 
karşılıksız yapılan dış yardımlar, insani yardımlar, hem uluslar arası hem de bölgesel kuruluşlara katılım ve iyi komşuluk politikası uygulamaları yer almaktadır. ${ }^{61}$

Pekin Konsensüsü teriminden ilk defa Goldman Sach Firmasının danışmanı ve Tsinghua Üniversitesi Öğretim Üyesi Joshua Cooper Ramo tarafindan Dış Politika Merkezi'nde

“ Pekin Konsensüsü” başlı̆̆ı ile Mayıs 2004'te yayınlanan makalede söz edilmiştir. ${ }^{62}$ Ramo'ya göre bu terim 3 teoremi içermektedir. "Birincisi Çin gelişme modelinin yenilikçi bir yapıda olduğunu belirtir, ikincisi bu modelin önceliği sürdürebilirlik ve eşitlik olduğunu ifade eder, üçüncüsü ise Çin'in dış politikada kendi başına hareket edebilmek için çabaladığını söyler." ${ }^{63}$ Dolayısıyla "Washington Uzlaşması" ${ }^{\prime 64}$ ndan farklı olarak yalnızca ekonomik değil, politik, sosyal ve diplomatik konuları da içermektedir.

Kavram ilk yayınladığında medyada geniş olarak yer almış ve birçok bilim adamı tarafından analize konu edilmiştir. Üçüncü Dünya'ya ait birçok ülke bu modeli kendi ülkelerine uyarlanabilir olarak görmüştür. Nitekim Asya, Afrika ve Latin Amerika'daki birçok gelişmemiş ülke bu model sayesinde kendi otoriter politik sistemini sürdürerek ekonomi alanında yükselişe geçmenin mümkün olduğuna inanmaya başlamıştır. Bu nedenle "Güney Asya, Afrika, Latin Amerika, Rusya ve Kazakistan, Özbekistan, Türkmenistan" ${ }^{65}$ gibi önceki Sovyet toplumları Çin'in gelişme modeline büyük ilgi göstermiştir.

Pekin Modeli yalnızca Çin'e ait olan bir gelişme modelinden ilk defa bahsedildiği için önem taşımaktadır. Bununla birlikte Pekin Konsensüsü Çin stili sosyalizmin uluslar arası alanda daha fazla tanınmasını ve destek bulmasını sağlamıştır. Ayrıca Çin, sürekli insan hakları ihlali yapan ve demokratik olmayan bir ülke duruşundan bu model vasıtasıyla kurtulmayı başarmıştır. Nitekim bugün ABD’nin karşısında uluslar arası toplum ile birlikte Üçüncü Dünya'ya yönelik gelişme politikaları tavsiyelerinde bulunma konusunda lider rol üstelenebilmektedir. ${ }^{66}$ Dolayısıyla bu modelin hem politikadan topluma her konuyu içinde barındırması hem de Çin' in içerideki ve dışarıdaki imajına olumlu katkılarda bulunması benimsenmesini kolaylaştırmış, özellikle otoriter rejime sahip ülkeler tarafından örnek alınması da Çin'in yumuşak gücüne katkıda bulunmuştur.

Çin'in yumuşak güç unsurlarından bir diğerini dış politikada benimsediği “ Barışçıl yükseliş” ya da “ Barışçıl gelişme" söylemi oluşturmaktadır. Çin'in kısa zamanda yükselen bir güç haline gelmesi ve özellikle kendi bölgesinde güçlenmesi kendisine komşu olan devletleri tedirgin etmiştir. Bu nedenle yükselişinin bir tehdit olmaktan ziyade avantaj olduğuna dair bölge devletlerini ikna etme çabası içine girmiştir. Bu nedenle özellikle Asya Bölge’sinde "Barışçıl Gelişme” teorisine önem verilmiştir.

Kasım 2005'te Devlet Enformasyon Ofisi tarafından yayımlanan raporda "Barışçıl gelişme" teorisi şu şekilde açıklanmıştır: ${ }^{67}$

“Birincisi barışçıl gelişme Çin'in modernizasyonu için kaçınılmaz bir yoldur. İkincisi Çin barışçıl küresel bir ortam yaratarak ve gelişmeler vasıtasıyla dünya barışına katkıda bulunarak gelişmelerini sürdürmektedir. Üçüncüsü Çin gelişmesini kendi kapasitesine, teknolojisine ve düzenlemelerine dayanarak gerçekleştirmektedir. Dördüncüsü Çin küreselleşme eğilimine uyum sağlamakta ve diğer devletlerle karşılıklı fayda ve ortak gelişmeyi

\footnotetext{
${ }^{61}$ Denise E. Zheng, China's Use of Soft Power in the Developing World: Strategic Intentions and İmplications for the United States, March 2009, s.3

62 Young Nam Cho, Jong Ho Jeong, a.g.m. s. 461

${ }^{63}$ Young Nan Cho, Jong Ho Jeong, a.g.m. , s.462

${ }^{64}$ Bu kavram ilk kez 1989 yılında John Willliamson tarafından kullanılmıştır. IMF ve Dünya Bankası gibi Kuruluşların düşüncelerini yansıtan ve temelde 1980'li yılların başından itibaren yapısal uyum programlarının IMF ve Dünya Bankası tarafından üyelerine uygulattırılan politikalar Washington Uzlaşması olarak isimlendirilmektedir. Özellikle 1950-1960’lardaki kalkınma ideolojisi ve uygulamalarının başarısızlığı küresel anlamda ön plana çıkmasını sağlamıştır. ( Serdar Öztürk, Ali Sözdemir, Bekir Gövdere, "Çin: Washington Uzlaşmasından Beijing Uzlaşmasına”, C.Ü İktisadi ve İdari Bilimler Dergisi , Cilt 7, Sayı 1, 2006. Erişim: http://iibfdergi.cumhuriyet.edu.tr/archive/\%C3\%87in:\%20washington\%20uzla\%C5\%9Fmas\%C4\%B1ndan\%20b eijing\%20uzla\%C5\%9Fmas\%C4\%B1na.pdf ( 30. 06. 2013)

${ }^{65}$ Young Nam Cho, Jong Ho Jeong, a.g.m. , s.466

${ }^{66}$ Young Nam Cho, Jong Ho Jeong, a.g.m., s.465

${ }^{67}$ Young Nam Cho, Jong Ho Jeong, a.g.m., s.468
} 


\section{Elif Sak}

sağlamak için çaba harcamaktadır. Beşincisi Çin, barış, gelişme ve işbirliği ilkelerine sadık kalarak sürekli barış ve zenginliğin olduğu uyumlu bir dünya inşa etmek için uğraşmaktadır."

Bu teori çerçevesinde Çin, hiçbir devlete karşı saldırgan bir tavır içinde bulunmamakta, diğer devletlerin toprak bütünlüğüne saygı duymakta, iç işlerine karışmamakta ve onlarla ilişkilerinde karşılıklı faydayı ve eşitliği gözetmektedir.

Barışçıl yükseliş politikası çerçevesinde Çin, kendisi için güvenli bir dış politika ortamı oluşturmayı, gerginlik ve çatışmalardan kaçınarak ekonomik olarak büyümeyi ve dünyaya açılmayı hedeflemektedir. "Temelde politika Çin'in Asya'da bir tehdit olarak görülmesini engellemek amacıyla benimsenmiş olsa da Çin bu ilke kapsamında küresel düzeyde ABD, Rusya ve AB ile stratejik ilişkiler kurmakta, Asya Pasifik’te Japonya, ASEAN ve APEC, doğuda Şanghay İşbirliği ile bölgesel barış kuşağı oluşturmaktadır." ${ }^{68} \mathrm{Bu}$ tür uluslar arası ve bölgesel organizasyonlara katılım da Çin'in uluslar arası alanda sorumluluk sahibi olduğunu göstermekte, ayrıca kendisini tehdit olarak gören ülkelerle işbirliği içinde olması diğer devletlerde Pekin'in yükselişinin barışçıl amaç taşıdığı yönünde algı oluşmasında etkili olmaktadır.

Çin'in en güçlü yumuşak güç unsurlarından bir diğerini Çin medeniyeti oluşturmaktadır. Nitekim uzun bir tarihi geçmiş ve köklü kültürel değerler, özellikle Asya'da yer alan ülkeler arasında, Çin’i bir adım öne çıkarmaktadır.

Çin'in son dönemlerde yükselişi ve özellikle Doğu Asya ülkelerinde Konfüçyanizmin değerlerinin benimsenmesi Çin medeniyetine dayanan Asya değerlerinin yeniden şekillendirilmesine ilişkin görüşlerin ortaya çıkışına zemin hazırlamıştır. Bahsedilen değerler arasında, aile, etik değerler, bireysellikten ziyade gruba önem verilmesi, birlik, düzen ve uyumun sağlanması, yoğun bir şekilde çalışma, kanaatkarlık ve eğitim yer almıştır. ${ }^{69}$ Aynı zamanda Konfüçyanizm diplomatik fikirlere de taşınmıştır. Bu bağlamda "Komşularla barıș içinde yaşama, onlara refah getirme ve onların güvenliğini sağlama" ve "uyumlu dünya" söylemleri Konfüçyüs'ün söylemlerinden gelmektedir. ${ }^{70}$ Dolayısıyla Konfüçyanizmin özellikle Doğu Asya bölgesinde benimsenen değerlerle benzerlik göstermesi Çin'in “Asya Değerleri”nin oluşturulması konusunda bölge devletlerinin desteğini almasını sağlamıştır. Aynı zamanda Konfüçyanizmin söylemlerinin diplomasi fikri olarak belirlenmesi de "Barışçıl Yükseliş” ilkesine temel oluşturarak Çin'in yumuşak gücüne katkıda bulunmuştur.

Konfüçyanizmin yanı sıra Çin medeniyetinin bir başka yumuşak güç unsurunu ülkenin kültürel mirası oluşturmaktadır. Çin kültürü diğer devletlerle ilişki kurma konusunda bir değer olarak benimsenmeden önce de Asya'ya ve dünyanın diğer bölgelerine yayılmıştır. Örneğin "kağıt, silah, porselen, ipek"71 Batı'dan önce Asya'da kullanılmıştır. Bununla birlikte özellikle "Eşitsiz Anlaşmalar” döneminde eski Çin felsefesi, geleneksel ilaçlar, dövüş sanatları, hat ve resim sanatı misyonerler, tüccarlar ve diplomatlar tarafından dünyaya tanıtılmıştır. ${ }^{72}$

Yakın dönemde geleneksel kültürel değerlerine ek olarak Çin, Batı'nın dikkatini daha fazla çekecek kültürel gelişmelere yoğunlaşmaya başlamıştır. Çeşitli ülkelerde resim galerileri açmış, edebiyat ve sinema alanlarında da kayda değer gelişmeler yaşanmıştır. ${ }^{73}$

1978'lerde başlayan reformlar sonucu kısa sürede hızlı bir büyüme geçekleştiren Çin için ekonomi de önemli bir yumuşak güç kaynağı haline gelmiştir. Çin'in hem otoriter bir rejime sahip olması hem de pazar ekonomisi anlayışını benimsemesi özellikle onunla benzer yönetim biçimini benimseyen "Kamboçya, Vietnam ve Laos"74 gibi gelişmekte olan ülkelerin dikkatini çekmiştir. Çin'in kendi değerlerine bağlı kalarak uluslar arası alanda yükselişe geçmesi bu devletler açısından örnek teşkil etmiştir.

\footnotetext{
${ }^{68}$ Denise E. Zheng, a.g.m., s.5

${ }^{69}$ Young Nam Cho, Jong Ho Jeong, a.g.m., s.470

70 Young Nam Cho, Jong Ho Jeong, a.g.m., s.471

71 Jaime Otero Roth, a.g.m., s.5

72 Jaime Otero Roth, a.g.m., s.5

73 Jaime Otero Roth, a.g.m., s. 5

${ }^{74}$ Gary D. Rawnsley, a.g.m. , s. 283
}

BARIŞ ARAŞTIRMALARI VE ÇATIŞMA ÇÖZÜMLERİ DERGİSİ http://dergi.cicr.org.tr/ 
Ekonominin Çin'in yumuşak gücüne katkı sağlayan diğer unsuru dışarıda gerçekleştirilen yatırımlardır. "Çin'in yatırım stratejisinin temelinde, ekonomik büyümenin istikrarlı ve sürekli olabilmesini sağlamak için enerji ve hammadde temini yer almaktadır. Enerji ve hammaddeye olan ihtiyaç da Çin'in Afrika, Latin Amerika ve Orta Doğu'daki ülkelere yaptığı ekonomik yatırımları teşvik etmektedir." ${ }^{\prime 5}$ Yapılan yatırımlarla birlikte Çin, petrol ve enerji kaynakları bakımından zengin olan Latin Amerika'daki Surinam gibi devletlere ayrıca karşılıksız yardımda bulunmaktadır. ${ }^{76}$ Yardımların Tayvan ile diplomatik ilişkilerin kesilmesi ve Tayvan'ın tanınmasından vazgeçilmesi dışında bir koşul içermemesi bahsedilen bölge ülkeleri açısından Çin'in ekonomik yardımlarını çekici hale getirmektedir.

Çin yumuşak güç unsurlarını dış dünyaya aktarmada diğer devletlerle benzer kamu diplomasisi araçlarını kullanmaktadır. Bunlar arasında "medya, internet, kutlamalar, organizasyonlar, yayınlar ve projeler" 77 yer almaktadır. Ancak bazı devletlerden farklı olarak bu araçların kullanımında devlet kontrolünün olması Çin'in kamu diplomasisi faaliyetlerini diğerlerinden ayırmaktadır.

Çin'in kendisini dışarıda tanıtmak için kullandığı en temel araçlardan birini medya faaliyetleri oluşturmaktadır. Ülke içerisinde 4 temel medya organizasyonu bulunmaktadır: Xinhua, China Central Television, China Radio International, China Daily. ${ }^{78}$

The Xinhua news Agency, dünya çapında 13.000 çalışanı ve Çin'de 40'ın üzerinde bulunan ofisleriyle ülkenin en büyük medya organizasyonudur. Çin dışında bulunan büroları ve 130 branştaki medya organizasyonları ile dünya çapında bir haber ajansı olabilmek için aktif bir şekilde çalışmaktadır. Ajans Çince multimedya servislerine Aralık 2008 'de başlamıştır. Temmuz 2009'dan beri de İngilizce yayın yapmaktadır. ${ }^{79}$

“China Xinhua News Network Corporation (CNC)" 1 Ocak 2010'da yayına başlamıştır. İlk başlarda yalnızca Çince haber programları ve özel haber bültenleri yayınlanmıştır. Temmuz 2010'dan itibaren CNC World News temel politik, ekonomik ve kültürel konularda İngilizce yayın yapmaya başlamıştır. İlk kurulduğunda yalnızca Asya-Pasifik bölgesinde ve birkaç Avrupa devletinde yayın gerçekleştiren CNC, 1 Ocak 2011'de tüm Avrupa ülkelerine ulaşmıştır. Ayrıca Orta Doğu'da ve Kuzey Afrika'da da yayın yapmaktadır. Sahra altı bölgedeki yaklaşık 50 ülkeden 4 milyonun üzerinde hane halkı CNC'nin İngilizce kanalından sinyal alabilmektedir. Yine Kanada ve Amerika'dan da kablolu bağlantı sayesinde CNC'nin İngilizce yayın yapan kanalı izlenebilmektedir. ${ }^{80}$

China Central Television, yeni yüzyılla birlikte yayın alanını evrensel boyuta taşımıştır. 2000'de, aynı zamanda CCTV-9 olarak da bilinen CCTV İnternational adıyla 7 gün 24 saat İngilizce yayın yapan kanal kurmuştur. ${ }^{81}$ Nisan 2010'da CCTV News olarak yeniden adlandırılmıştır. Kanal, son zamanlarda 100'den fazla ülkede 85 milyonun üzerinde seyirciye ulaşmaktadır. ${ }^{82}$

2004 yılında Fransızca ve İspanyolca olmak üzere iki dilde yayın yapan E\&F kanalı kurulmuştur. ${ }^{83}$ Bununla birlikte Temmuz 2009'da Orta doğu, Kuzey Afrika ve Asya Pasifik Bölgesinde 22 Arap ülkesinde 300 milyon seyirciye ulaşan yeni bir kanal ve Eylül 2009'da Pekin ve Moskova arasında diplomatik ilişkilerin kurulmasının 60.yıl dönümü vasıtasıyla CCTV- Rusya yayına başlamıştır. ${ }^{84}$ Birçok dilde yayın yapan CTTV kanalının

\footnotetext{
${ }^{75}$ Denise E. Zheng, a.g.m., s.3

${ }^{76}$ Emine Akçadağ, a.g.m., s. 183

${ }^{77}$ Hesserbani Anja Lejli, a.g.m., s.5

${ }^{78}$ Shi Li, Propagating China to the World: "Public Diplomacy through the Media" Strategy in the Age of Globalization, 26 Nisan 2013, http:// gnovisjournal.org/2013 /04 /26/propagating-china-to-the-world-chinaspublic-diplomacy-through-media-strategy-in-the-age-of-globalization/

${ }^{79}$ Shi Li, a.g.m., s.4

80 Shi Li, a.g.m., s.4

${ }^{81}$ Xiaoling Zhang, Chinese State Media Going Global, s.45, Erişim: http://www.eai.nus.edu.sg/Vol2No1 ZhangXiaoling.pdf (30.06.2013)

82 https://en.wikipedia.org/wiki/CCTV News

${ }^{83}$ Xiaoling Zhang, a.g.m., s.45

${ }^{84}$ Shi Li, a.g.m., s.5
} 


\section{Elif Sak}

bulunmasının yanı sıra, CCTV aynı zamanda Çin vatandaşı olmayan muhabirlere ve sunuculara iş imkanı da sağlamaktadır. ${ }^{85}$

Aralık 2009'da İngilizce, İspanyolca, Arapça ve Rusça gibi çeşitli dillerde yayın yapan Internet üzerinden erişim sağlayan CNTV kurulmuştur. ${ }^{86}$

China Radio İnternational (CRI), 1941 'de kurulmuştur ve günümüzde 58 dilde yayın yapmaktadır. 2000 y1lında Londra merkezli Dünya Radyo Ağı(WRN) isimli özel şirketle birleşmesinin ardından radyo ve televizyon yayınları için geçiş servisleri sağlanmıştır. CRI'nın aynı zamanda 117 tane uluslar arası FM ortağı ve Asya, Afrika, Kuzey Amerika, Avrupa ve Avusturalya'da da 32 AM radyo ortağı bulunmaktadır. ${ }^{87}$

China Daily, 1981'de Çin'de kurulmuştur. Amerika'da ilk olarak 2009 yılında New York'ta İngilizce yayıma başlamıştır. Amacı Kuzey Amerika'nın iş dünyası hakkında haber vermek ve Çin'in hızlı ekonomik, kültürel ve politik değişimleri hakkındaki gözlemleri aktarmak olmuştur. ${ }^{88}$ 2009'dan beri gazete ABD'nin New York, Washington D.C. , Chicago, San Francisco, Los Angeles ve Houston olmak üzere 6 önemli şehrinde ofis açmıştır. ${ }^{89}$

Küresel anlamda hakimiyet sağlayabilmek amacıyla dijital teknoloji alanındaki gelişmeler de yakından takip edilmiştir. Internet sitesi 1994 yılında kurulmuş, hem Çince hem de İngilizce yayın yapılmıştır. 2010 y1lında yayınları arasına Fransızca da eklenmiştir. ${ }^{90}$

Geleneksel medyanın yanında Çin, interneti de etkili bir biçimde kamu diplomasisi aracı olarak kullanmaktadır. Enformasyon Ofisi tarafindan propaganda/kamu diplomasisi amacıyla düzenlenen siteler birçok dilde Çin hakkında bilgiye erişimi sağlamaktadır. Bununla birlikte Dış İşleri Bakanı dahil olmak üzere birçok bakana tweeter ve facebook üzerinden ulaşmak mümkün olmaktadır. ${ }^{91}$

Medya ve internet gibi yayın organları dışarıya daha çok Çin'in ekonomik, politik ve sosyal durumuna ilişkin bilgi aktarmayı amaçlarken kültürün aktarılmasında medya dışında çeşitli kamu diplomasisi araçları kullanılmaktadır.

Konfüçyüs Enstitüleri Çin kültürünün tanıtılmasında en yaygın kullanılan kamu diplomasisi aracı niteliğindedir. İlki Kasım 2004'te açılan Konfüçyüs Enstitülerinin sayısı Ekim 2010 itibariyle 322'ye ulaşmış ve 2020'ye kadar da 1000'i bulması hedeflenmiştir. ${ }^{92}$ Diğer ülkelerle iyi ilişkiler kurmak ve dünyada Çin dilinin ve kültürünün anlaşılmasını sağlamak için kurulan enstitülerde Çince öğretilmekte, ülkenin kültürü anlatılmakta ve değişim programları düzenlenmektedir. ${ }^{93}$

Çin kültürünün dünyaya tanıtılmasında kullanılan önemli bir araç da ülkede düzenlenen organizasyonlardır. Bu bağlamda Çin dünyada kendisinin görünürlüğünü arttıracak birtakım organizasyonlara ev sahipliği yapmıştır. Örneğin 1990'da “Asya Oyunları ve BM Uluslar arası Kadınlar Konferansı"94 Çin'de gerçekleşmiştir. Ancak uluslar arası organizasyonlar arasında 2008 Olimpiyatlarının Çin'de düzenlenmesi ülkenin dışarıdaki imajına farklı bir etkide bulunmuştur. 8 Ağustos 2008 tarihinde gerçekleştirilen organizasyon dünyada eş zamanlı olarak birçok seyirci tarafından izlenmiş ve görkemli bir şekilde gerçekleştirilen açılış seremonisi büyük yankı uyandırmıştır. Çin ev sahipliğini yaptığı bu olimpiyat sayesinde spora ve sporcuya değer veren bir ülke imajı yaratmayı başarmıştır. Aynı zamanda Olimpiyat Komitesi bu fırsatı değerlendirerek dünyanın çeşitli ülkelerinden

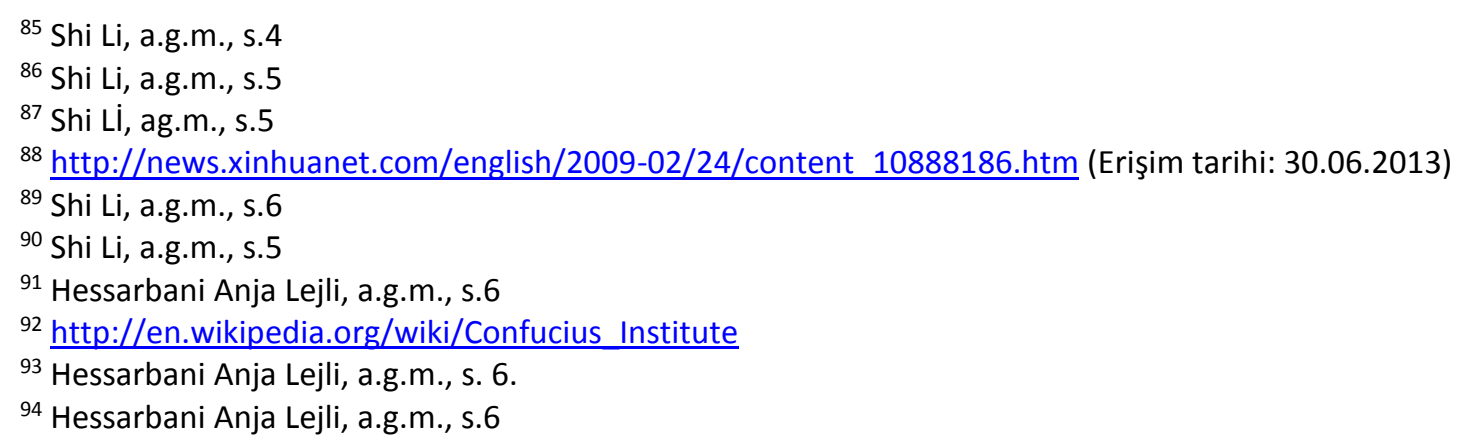

BARIŞ ARAŞTIRMALARI VE ÇATIŞMA ÇÖZÜMLERİ DERGİSİ http://dergi.cicr.org.tr/ 
gelen ziyaretçiler ve sporcularla dostluk kurmuştur. 51 altın, 21 gümüş ve 28 bronz madalya kazanan Pekin bu sayede yumuşak gücünü başarılı bir şekilde göstermiştir. ${ }^{95}$ Uluslar arası alanda gerçekleştirilen organizasyonların yanı sıra "Chinese Culture Weeks" gibi daha küçük faaliyetler de gerçekleştirilmektedir. ${ }^{96}$

İşbirliğinin ön plana çıktığı etkinliklerle birlikte Çinli sporcuların bireysel başarıları da Çin kültürünün dışarıya aktarılmasında önemli bir faktördür. Örneğin NBA takımı Houston Rockets'ın Çinli yıldızı Yao Ming yeni bir Michael Jordan haline gelmiştir. ${ }^{97}$ Özellikle Asyalı taraftarlara Çin imajının yansıtılmasında yardımcı olmaktadır.

Konfüçyüs Enstitüleri gibi kurumsal yapılar ve bölgesel veya uluslar arası alanda gerçekleştirilen faaliyetlerin yanında dünyanın çeşitli yerlerinde açılan Çin restoranları ve eğlence parkları da ülke kültürünün dünyaya tanıtılmasında önemli kamu diplomasisi araçlarıdır. "Batı'da açılan restoranlarda, kültür tanıtımı yapmak amacıyla hem geleneksel yemekler kullanılmakta hem de sunumun yöresel kıyafetlerini giyen Çinliler tarafından kendi ülkelerine ait müzikler eşliğinde gerçekleştirilmesine özen gösterilmektedir." 98 "Eğlence parkları ise politik bir nitelik taşımamakla birlikte daha çok Tibet ve Uygur kültürüne de değer verildiği mesajının iletilmesi için kullanılmaktadır." ${ }^{99}$ Dolayısıyla Çin kültürünün dışarıya tanıtılmasında restoranlar ve eğlence parkları vasıtasıyla yurttaşlar düzeyinde gerçekleştirilen kamu diplomasisi faaliyetleri önemli bir rol oynamaktadır.

Çin'in kamu diplomasisi stratejisinde kişisel olarak gerçekleştirilen faaliyetler de yer almaktadır. Her yıl çok sayıda öğrenci başka ülkelere gitmekte ve ülkeye eğitim görmek amacıyla çok sayıda öğrenci gelmektedir.1992'de sadece 6.540 Çinli öğrenci yurt dışında eğitim görürken bu rakam 2002'de 125.179'a yükselmiştir. 2006 y1lında dışarıda eğitim gören Çinli öğrenci sayısı 1 milyonu geçmiştir. ${ }^{100}$ Sadece 2011 yılı içerisinde ise yaklaşık 340.000 öğrenci yurt dişında eğitim almıştır. ${ }^{101}$

Ülkede 2011 yılında yaklaşık 290.000 yabancı uyruklu öğrenci eğitim görmüştür. Rakamlara bakıldığında çoğunluğu Güney Kore'den( 62,442), ardından sırasıyla Amerika'dan( 23.292), Japonya'dan (17, 961), Rusya'dan $(13,340)$, Endonezya'dan(10, 957) ve Hindistan'dan $(9,370)$ gelen öğrencilerin oluşturduğu görülmektedir. ${ }^{102}$ Bununla birlikte Çin'in eğitim sektörüne ilişkin 5 yıllık planı 2020'ye kadar ülkede yaklaşık 500.000 yabancı öğrenciyi ağırlayacak kadar eğitim kurumu inşa etmeyi hedeflemektedir. ${ }^{103}$

\section{ÇİN'İN YUMUŞAK GÜCÜNÜN SINIRLARI ve SONUÇ}

Çin izolasyon politikasını terk ettikten sonra etkili kamu diplomasisi çalışmaları başlatmıştır. Ülkenin amaçlarını doğru bir şekilde aktarabilmek ve dışarıya kendisini en iyi şekilde tanıtabilmek için çeşitli alanlarda kamu diplomasisi faaliyetleri yürütmeye başlamıştır. Ancak, Çin'in bu süreçte bertaraf etmesi gereken birçok engel de bulunmaktadir.

Çin 1979'larda başlayan ekonomik reformlar sonucunda yaklaşık 30 yıl sonra yükselen bir güç haline gelmiş ve dünyada kendi değerlerinden vazgeçmeden de ekonomik bir güç olunabileceğinin örneğini teşkil etmiştir. Ancak ülke ekonomisi kısa zamanda büyük gelişme gösterse de bu durum Çin vatandaşlarının hayat standartlarına yansımadığı için halkın ayaklanmasına neden olmuştur. Ülke içinde bu tür sorunlarla karşılaşan Çin, uluslar arası alanda da işçilerin sağlığının ihmal edilmesi ve iş güvenliğinin sağlanmaması konusunda eleştirilere maruz kalmıştır. Ayrıca 1989 Tiannanmen Meydanı'nda yaşanan insan hakları ihlalleri uzun süre uluslar arası alanda

\footnotetext{
95 Ming Lee, a.g.m., s.13

${ }^{96}$ Hessarbani Anja Lejli, a.g.m., s.6

97 Joseph Nye, Dünya Siyasetinde Başarının Yolu Yumuşak Güç, Elips Kitap, Birinci Basım, Ekim 2005, s.91

${ }^{98}$ Hessarbani Anja Lejli, a.g.m. s.8

${ }^{99}$ Hessarbani Anja Lejli, a.g.m. s.8

100 Gary D. Rawnsley, a.g.m., s. 288

101 http://english.caixin.com/2012-09-25/100441943.html

102 http://edition.cnn.com/2013/05/29/world/asia/china-soft-power-foreign-students

103 http://edition.cnn.com/2013/05/29/world/asia/china-soft-power-foreign-students
} 


\section{Elif Sak}

gündemden düşmemiştir. Bununla birlikte Tibet ve Sincan Uygur Bölgesinde yaşanan insan hakları ihlalleri hala uluslar arası toplumun tepkisini çekmektedir.

Çin'in dışarıdaki imajını zedeleyen en büyük unsurları ise otoriter rejimlere karşı olan desteği ve Tayvan konusunda gerekirse güç kullanmaktan çekinmeyeceğine ilişkin açıklamaları oluşturmaktadır. ${ }^{104}$

Bir ülkenin ekonomisinin iyi olması ve zenginleşmesi önemli olsa da yalnızca bu faktörlerin varlığı o ülkenin dışarıda sevildiği anlamına gelmemektedir. Bu açıdan bakıldığında Çin yakın dönemde ekonomik bir güç olarak ortaya çıkmasına rağmen zayıf geçmişi ve yukarıda bahsedilen durumlar nedeniyle yeni Çin imajını dünyaya kabul ettirme konusunda zorluk çekmektedir. Bu bağlamda uluslar arası araştırmalar da Çin'in imajının ülkelere göre değiştiğini göstermektedir. Örneğin “Orta Doğu ve Afrika ülkeleri” Çin hakkında daha olumlu düşüncelere sahipken, "ABD ve Avrupa" ${ }^{105}$ negatif yönde düşüncelere sahiptir.

Çin'in önünde birçok engel olmasına rağmen gerçekleştirdiği kamu diplomasisi faaliyetlerinin ülke hakkında olumlu imaj yaratılmasında önemli bir yere sahip olduğu da yadsınamaz bir gerçektir. Ülkenin kısa sürede ekonomik olarak yükselişe geçişi Çin'in yumuşak gücünün artışına en büyük katkı sağlayan unsur olsa da bunun yanında dışarıdaki yatırımların arttırılması, herhangi bir koşul ileri sürmeden gelişmemiş ya da gelişmekte olan ülkelere yapılan dış yardımların sürdürülmesi, kültürünü aktarabilmek için çeşitli kamu diplomasisi araçlarını kullanması Çin hakkında uluslar arası alanda olumlu bir itibarın oluşmasını sağlamaktadır.

${ }^{104}$ Emine Akçadağ, Kamu Diplomasisi, "Yükselen Güç Çin'in Kamu Diplomasisi”, Ed. Yrd. Doç Dr. Abdullah Özkan, Tuğçe Ersoy Öztürk, Tasam Yayınları, İstanbul, Birinci Basım, 2012, s. 184

${ }^{105}$ Emine Akçadağ, a.g.m., s.184 


\section{KAYNAKÇA}

NYE, Joseph S.(Ekim 2005). Dünya Siyasetinde Başarının Yolu Yumuşak Güç, Elips Kitap

DEMIR, Vedat (Kasım 2012).Kamu Diplomasisi ve Yumuşak Güç, Beta yayınları

SANCAR, Gaye A.(Temmuz 2012). Kamu Diplomasisi ve Uluslar arası Halkla İlişkiler, Beta yayınları

CULL, N.J. (2009). Public Diplomacy: Lessons from the Past, Los Angeles, Figueroa Press

SNOW, Nancy,(2009). Persuader-in-chief: Global Opinion and Public Diplomacyin the Age of Obama, Nimble Books

AKÇADAĞ, Emine. Avrupa Birliği Sürecinde Kamu Diplomasisi Faaliyetlerinde Sivil Toplum Kuruluşlarının Rolü

DRAPAU,Mark (2013). “Corporate Public Diplomacy: Engaging and İmproving Stakeholder Communities”

LEJLİ Hessarbani Anja(2011). Public Diplomacy of Peopşe's Republic of China

RAWNSLEY Gary D. China Talks Back

LEE Ming (2009). Chaina’s Public Diplomacy: A Useful Smart Power, Arı Working Paper Series No.10

PRİCE Monroe E., DAYAN Daniel, Owning the Olympics: Narratives of the New China

CHO Young Nam, JEONG Jong Ho, China's Soft Power: Discussions, Resources and Prospercts, Asian Survey

ZHENG Denise E(2009). China's Use of Soft Power in the Developing World: Strategic Intentions and İmplications

http://news.xinhuanet.com/english/2009-02/24/content_10888186.htm (Erişim tarihi: 30.06.2013)

LI Shi(2013), Propagating China to the World: "Public Diplomacy through the Media" Strategy in the Age of Globalization

ZHANG Xiaoling , Chinese State Media Going Global, s.45, Erişim:http://www.eai.nus.edu.sg/Vol2No1_ZhangXiaoling.pdf

ÖZTÜRK Serdar, Ali Sözdemir, Bekir Gövdere, "Çin: Washington Uzlaşmasından Beijing Uzlaşmasına”, C.Ü İktisadi ve İdari Bilimler Dergisi , Cilt 7, Sayı 1, 2006. Erişim: http://iibfdergi.cumhuriyet.edu.tr/archive/\%C3\%87in:\%20washington\%20uzla\%C5\%9Fmas \%C4\%B1ndan\%20b eijing\%20uzla\%C5\%9Fmas\%C4\%B1na.pdf

http://english.caixin.com/2012-09-25/100441943.html

http://edition.cnn.com/2013/05/29/world/asia/china-soft-power-foreign-students

http://news.xinhuanet.com/english/2009-02/24/content_10888186.html

https://en.wikipedia.org/wiki/CCTV_News 